\title{
ノ一ベル物理学賞は量子光学研究に
}

\section{Physics prize puts spotlight on optics}

\section{光の量子的性質の理解から大きな進展が得られた。}

doi:10.1038/437800a/4 October 2005

Jim Giles, Additional reporting by Alison Abott

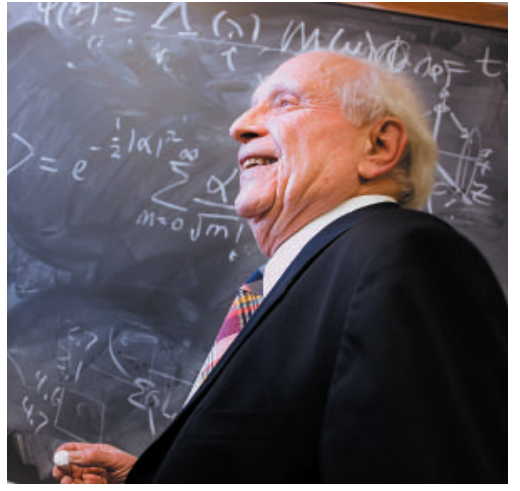

ハーバード大学 (米) のロイ・グラウバー教授 (80 歳)。

量子力学を光に応用し、また物理学の 基本定数の測定にあたり、これまでで 最も高い精度をもつ装置を作った 3 人 の研究者が、今年のノーベル物理学賞 を受賞した。

賞金の半分は、この進歩の基礎を築 いた理論家であるロイ・グラウバーに 贈られる。グラウバーは、1976 年から ハーバード大学で物理学の教授を務め ており、マンハッタン計画 (第 2 次世 界大戦時の原子爆弾開発計画）にも参 加した。

賞金の残り半分は、原子や分子が放 出する光の振動数を測定する技術を開 発した、米国立標準技術研究所のジョ ン・ホールとドイツのマックスプラン ク量子光学研究所のテオドール・ヘン シュに贈られ、2人で分ける。

受賞のニュースを聞いたとき、ヘン シュは大学にいて、米国へ向かうフラ イトのための荷造りで忙しくしていた。 しかしその 30 分後、彼は大学の部屋へ 詰めかけてきた 100 人もの記者の応対 に追われていた。記者たちは、彼の人 生のすべてを聞きだそうとした。ヘン シュは「ノーベル賞を受賞するとは考 えてもいなかった。困惑していて、ま

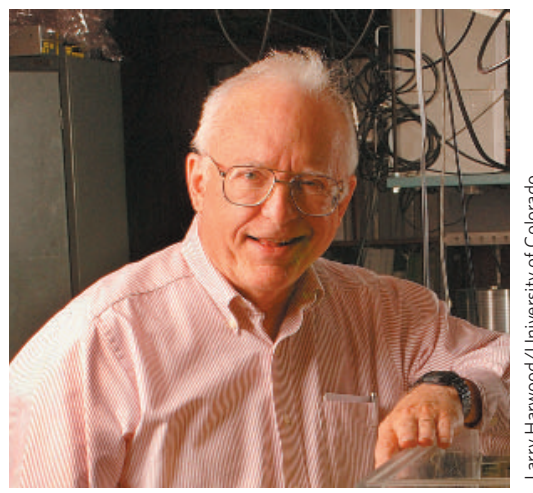

国立標準技術研究所 (米) のジョン・ホール 上席研究員 (71 歳)。

だこの事実を受け入れることができて いない」と話す。

ホールとヘンシュの研究は、グラウ

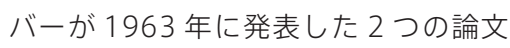
をもとにしたものだ。っグラウバーの論 文は、1950 年代にレーザーが開発され て物理学界に沸き起こった興奮を背景 に誕生した。論文で扱われたのは、レ ーザーなどから出る光子の測定に使う 装置の働きだ。グラウバーは、通常の 統計では光子と検出器の間の相互作用 を記述できず、装置の量子的性質を理 解してはじめて、その相互作用を説明 できることを示した。

「光コム」の開発 グラウバーはこの成果により、確立さ れた量子論を光に応用する量子光学と いう新分野の中心人物となった。この 学問分野の成果は、レーザーの理解や、 励起した原子と分子が光子を放出する プロセスの理解を進めたことだった。 ホールとヘンシュはそれぞれがこうし た成果を応用して、高精度で光源の振 動数を測定できるレーザー装置である 「光コム」を作った。 ナビゲーションから宇宙論までに至

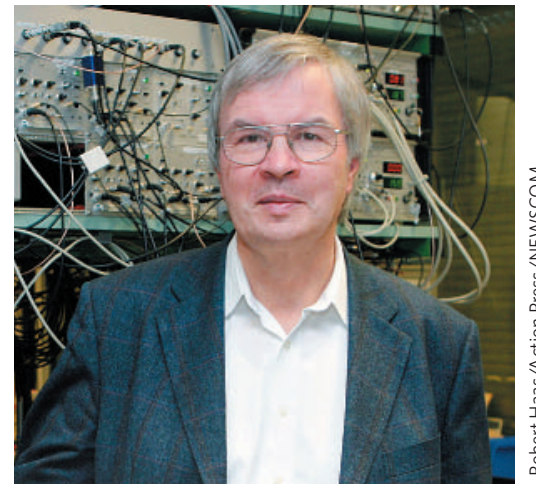

マックスプランク量子光学研究所 (ドイッ) のテオドール・ヘンシュ教授 (63 歳)。

る多様な分野が、光コムの恩恵を受け ている。光コムを使うと $10^{18}$ 分の 1 の 精度の振動数測定が可能とみられ、光 コムは新世代の光学時計の開発に使わ れている。光と物質の相互作用の強さ を決める微細構造定数を研究している 研究者たちは、この光学時計を使って、 時間とともに微細構造定数がわずかに 変化するか否かを調べている。こうし た装置は、「1秒」の再定義や、全地球 測位システム（GPS）が出すナビゲー ション信号の精度改善にもつながる可 能性がある。 